\title{
Penerapan Model Literasi Digital Berbasis Sekolah Untuk Membangun Konten Positif Pada Internet
}

\author{
Jamilah Karaman ${ }^{1}$, Ida Widaningrum²*, Mohammad Bhanu Setyawan³, \\ Sugianti ${ }^{4}$ \\ 1,2,3,4 Universitas Muhammadiyah Ponorogo \\ Email:jamilah@umpo.ac.id ${ }^{1}$,iwidaningrum@umpo.ac.id², m.banu@umpo.ac.id², \\ sugianti@umpo.ac.id ${ }^{4}$ \\ *Corresponding author: Ida Widaningrum
}

\begin{abstract}
ABSTRAK
Internet membawa dampak positf bagi kehidupan remaja karena mudah untuk mendapatkan informasi terbaru, meningkatkan kreatifitas dan mempermudah komunikasi dengan teman ataupun orang lain. Teknologi internet juga memberi dampak negatif yang mempengaruhi martabat kedirian dan kehidupan remaja. Munculnya beragam kasus cybercrime, adiksi terhadap pornografi dan game online, menjadi bukti sangat rentannya pengaruh negatif perkembangan internet terhadap remaja. Kecakapan literasi digital, merupakan salah satu langkah preventif dan edukatif untuk menyadarkan dampak positif dan meminimalisir dampak negatif internet. Sekolah, bisa menjadi penggerak utama untuk mengkampanyekan dan memberikan kecakapan literasi digital kepada siswa. Namun ada beberapa permasalahan untuk menerapkan literasi digital di sekolah. Pertama, belum adanya kurikulum kecakapan literasi digital yang diterapkan di semua sekolah. Kedua, masih minimnya kecakapan literasi digital yang dimilliki oleh para guru yang bisa menjadi penggerak. Hal ini juga terjadi di Madrasah Aliyah Negeri 2 Ponorogo, sehingga perlu diadakan workshop literasi digital berbasis sekolah untuk menunjang keberhasilan budaya gerakan literasi sekolah. Berdasarkan evaluasi workshop literasi digital, Hasilnya $>80 \%$ peseta memahami dan menguasai kompetensi informasi personal dan privasi, peserta mampu merespon dengan baik materi dan evaluasi kompetensi standard. Peserta mampu memahami semua materi informasi personal dan privasi, jejak digital dan kemanan Wi-Fi.
\end{abstract}

Kata Kunci: cybercrime; literasi digital; madrasah.

\section{Application of School Based Digital Literacy Model To Build Positive Content On The Internet}

\begin{abstract}
The internet has a positive impact on teenagers' lives because it is easy to get the latest information, increase creativity and facilitate communication with friends or others. Internet technology also has a negative impact on the dignity of selfhood and the lives of adolescents. The emergence of various cases of cybercrime, addiction to pornography and online games, is very evidence of the vulnerability of the negative influence of internet development on adolescents. Digital literacy skills are one of the preventive and educative steps to realize positive impacts and minimize the negative impacts of the internet. Schools, can be a prime mover to campaign and provide digital literacy skills to students. But there are some problems for implementing digital literacy in schools. First, there is no digital literacy skills curriculum implemented in all schools. Second, the lack of digital literacy skills possessed by teachers who can be a mobilizer. This also happened in Madrasah Aliyah Negeri 2 Ponorogo, so a school-based digital literacy workshop was needed to support the
\end{abstract}


success of the culture of the school literacy movement. Based on the evaluation of digital literacy workshops, the result is $>80 \%$ of participants has completed three basic competencies, privacy information, digital footprint and WI-FI security. The response of participants to the implementation of the digital literacy workshop was very good.

Keywords: cybercrime; digital literacy; madrasah.

\section{PENDAHULUAN}

Data statistik tentang pengunaan internet di Indonesia berdasarkan jenjang pendidikan, untuk kategori SD sebesar 9,82\%, SMP 35,53\%, SMA 61,64\%, Diploma/S1 83,97\%, S2/S3 $87,5 \%$ dan tidak sekolah 6,73\% (APJII, 2018). Data spesifik penggunaan internet yang dilakukan oleh anakanak saat mengakses internet adalah bermain game, menonton film/video, berkomunikasi lewat media sosial seperti Facebook, Instagram, Twitter serta chatting melalui WhatsApp dan Viber (Triastuti et al., 2017).

Penggunaan media berdasarkan jenjang pendidikan SD sebesar $76,89 \%$, SMP 82,63\%, SMA 97,5\%, Diploma/S1 97,55\%, tidak sekolah 73,3\% (Kemenkominfo, 2017). Melihat data tersebut, prosentase penggunaan media sosial oleh anak jenjang SMP dan SMA yang notabene disebut sebagai remaja sangat tinggi.

Tidak bisa dipungkiri bahwa internet membawa dampak positif (Aprilia, 2014) bagi kehidupan anak dan remaja karena memudahkan mereka untuk mendapatkan informasi terbaru, memudahkan mencari informasi terkait tugas dan pelajaran sekolah yang dapat meningkatkan kreatifitas anak (Urrohman, 2018), memperat komunikasi antar teman disekolah dan lain-lain. Seperti dua sisi mata uang, teknologi internet juga memberi dampak negatif yang mempegaruhi martabat kedirian dan kehidupan generasi remaja sekarang ini. Munculnya beragam kasus online pornografi dan cybercrime, kasus perundungan, adiksi terhadap pornografi dan games online bahkan menyebabkan jarak antara anak dan keluarga adalah bukti nyata sangat rentannya pengaruh negatif perkembangan modernisasi internet terhadap dunia anak (CNN, 2018) (Urrohman, 2018).

Kecakapan literasi digital, merupakan langkah preventif dan edukatif untuk menyadarkan dampak positif dan negatif dunia internet sekaligus meminimalisir dampak-dampak negatif yang terjadi. Literasi digital adalah kemampuan menggunakan teknologi informasi dan komunikasi (TIK), untuk menemukan, mengevaluasi, memanfaatkan, membuat dan mengkomunikasikan konten atau informasi, dengan kecakapan kognitif maupun teknikal (Syaripudin et al., 2017).

Orang tua sebagai pihak yang paling bertanggungjawab dalam pengawasan anak dalam penggunaan intenet, seharusnya mempunyai kecakapan literasi digital agar bisa mencegah dan meminimalisir dampak negatif teknologi yang mungkin akan menjerumuskan anaknya. Namun hal ini menjadi kendala, mayoritas orang tua tidak memiliki kecapakan literasi digital karena pendidikan yang pernah 
dienyam oleh orang tua belum pernah diberi keterampilan literasi digital. Program pencegahan berbasis sekolah relatiflebihmudahuntukdilaksanakan, sebab lebih terstruktur, sehingga lebih mudah untuk memantaunya (Salainty et al., 2015).

Madrasah Aliyah Negeri 2 Ponorogo, merupakan salah satu sekolah yang sudah menerapkan budaya literasi yang termanifestasi dalam gerakan literasi sekolah. Salah satu program literasi sekolah yang dijalankan adalah literasi perpustakaan, literasi media, literasi visual dan literasi teknologi dan digital (Tim GLN Kemendikbud, 2017). Perlu disadari bahwa guruguru pada umumnya rabun membaca, wawasan guru seringkali tertinggal oleh siswanya. Ketika siswa asyik berselancar di dunia maya dan melahap semua infomasi yang tidak terbatas, sementara sebagian guru masih masih buta teknologi internet. Padahal bergaul dengan internet membutuhkan kesadaran dan daya kritis tersendiri, sehingga perlu dipikirkan literasi digital sebagai ancaman jika tidak diiringi pemanfaatan oleh sekolah dan para guru.

Ada beberapa kendala dalam mengiplementasikan literasi digital di sekolah. Salah satunya adalah, tidak adanya kurikulum kecakapan literasi digital yang diterapkan disekolah, dihapusnya mata pelajaran TIK dari kurikulum 2013 yang seharusnya bisa menjadi media penyuluhan literasi digital (Puspito, 2015).

Melihat dari beberapa permasalahan dan kendala yang di alami MAN 2 Ponorogo, maka perlunya pelatihan literasi digital berbasis sekolah untuk menunjang keberhasilan budaya gerakan literasi sekolah. Selain itu diperlukan gerakan kampanye kepada warga sekolah tentang pentingnya literasi digital, diperlukan standard yang jelas tentang kompetensi yang diharapkan kepada siswa tentang keterampilan literasi digital, dan perlu kerjasama yang komprehensif antara perguruan tinggi dengan MAN 2 Ponorogo agar transfer pengetahuan tidak tersendat.

\section{METODE PENELITIAN}

Melihat rumusan masalah yang dipaparkan sebelumnya, maka dibuatlah strategi untuk menyelesaikannya dalam bentuk kegiatan PKMS di Madrasah Aliyah Negri 2 Ponorogo, yaitu sebagai berikut:

1. Pelatihan penggunaan dan pemanfaatan internet dan media social, sesuai dengan kerangka literasi digital yang di standarkan oleh pemerintah Indonesia bagi para siswa

2. Pelatihan membuat desain spanduk atau poster, yang akan ditempelkan di tempat strategis sekolah tentang pentingnya literasi digital sebagai bagian dari kampanye literasi digital.

3. Membuat evaluasi berupa penilaian akhir, dimana semua perserta harus lulus kompetensi literasidigitaldenganmengerjakan soal studi kasus berbentuk pilihan ganda dengan pencapaian nilai minimal $80 \%$. 
4. Pendampingan dan pendampingan secara berkesinambungan selama 3 bulan, yang berfokus pada pemahaman literasi digital kepada peserta pelatihan.

\section{HASIL DAN PEMBAHASAN}

Berdasarkan permasalahan dan temuan yang di hadapi oleh mitra maka disusun rencana kegiatan menggunakan beberapa tahapan yaitu: persiapan, pembekalan, pelaksaanan, pendampingan, monitoring, evaluasi dan rencana keberlanjutan.

Proses pelaksanaan dibagi menjadi beberapa kegiatan yaitu seminar, workshop, pembuatan spanduk dan uji kompetensi yang diberikan kepada guru dan murid.

Rangkaiankegiatanyang dilaksanakan sebagai berikut:

1. Hari Pertama Workshop bagi siswa MAN 2 Ponorogo yang akan dibagi menjadi empat sesi, dengan alokasi waktu mulai dari jam 09.00 sampai dengan jam 16.00 WIB.
a. Sesi I "Internet"
b. Sesi II "Privasi dan Perlindungan data pribadi"
c. Sesi III "Jejak Digital"
d. Sesi IV "WI -FI Publik"
e. Sesi V Sosialisasi literasi digital di lingkungan sekitar

2. Pendampingan

Pada tahap ini mahasiswa dibantu dengan dosen pembimbing berkolaborasi dengan OSIS MAN 2 Ponorogo dalam pembuatan stiker, poster dan spanduk. Stiker, poster dan spanduk ini akan ditempel di berbagai sudut sekolah dan dibagikan ke siswa sebagai bagian dari kampanye literasi digital.

3. Monitoring dan Evaluasi

Tahapan monitoring dan evaluasi dalam pelaksanaan kegiatan dilakukan oleh beberapa pihak yakni tim pengabdi, MAN 2 Ponorogo dan internal kampus. Monitoring dan evaluasi dilakukan guna menjawab pertanyaanpertanyaan seputar kegiatan pengabdian. Hasil evaluasi, dapat digunakan sebagai umpan balik bagi semua pihak.

\section{Pelaksanaan Kegiatan}

Kegiatan dilaksanakan dengan durasi pelatihan membutuhkan waktu 8 jam pelajaran dan 2 jam untuk evaluasi pemahaman yang sudah didapatkan. Evaluasi dilakukan secara online dimana peserta bisa mengakses secara online dan hasilnya bisa diketahui secara real time. Materi yang diberikan yaitu: Internet, Privasi dan Perlidungan data pribadi, jejak digital dan WI - FI Publik.

\section{A. Sesi Pertama}

Pada sesi pertama, peserta di ajak menonton video yang ada di link https://www.youtube.com/

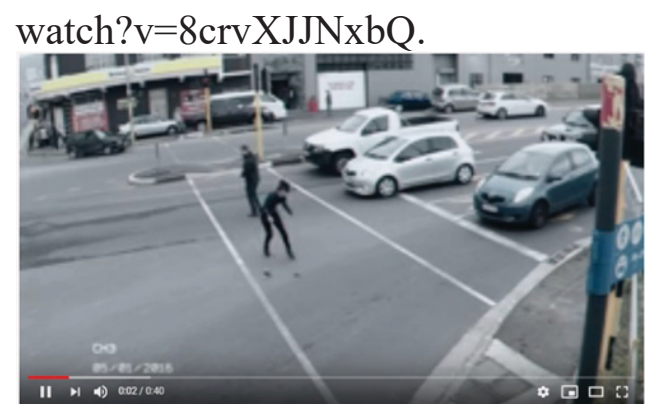

Gambar 1. Dampak Penggunaan Smartphone

Setelah menonton video, peserta harus mengisi pertanyaan analisis 
terkait video tersebut, melakukan pretest awal untuk mengetahui sejauh mana pengetahuan dari peserta tentang internet, dan juga bagaimana menggunakan internet. Ada 10 pertanyaan yang harus diisi oleh peserta, terkait penguasaan internet. Dari 10 pertanyaan yang diberikan, ada empat pertanyaan yang mayoritas jawabannya tidak sesuai ekspektasi. Kelemahan penguasaan internet yang mayoritas dilakukan peserta adalah, tidak bisa membedakan informasi pribadi dan informasi privasi. Peserta belum paham bahwa, aktivitas online yang dilakukan pasti akan meninggalkan jejak digital dan bagaimana penggunaan WI-FI publik yang aman dan teriamin.

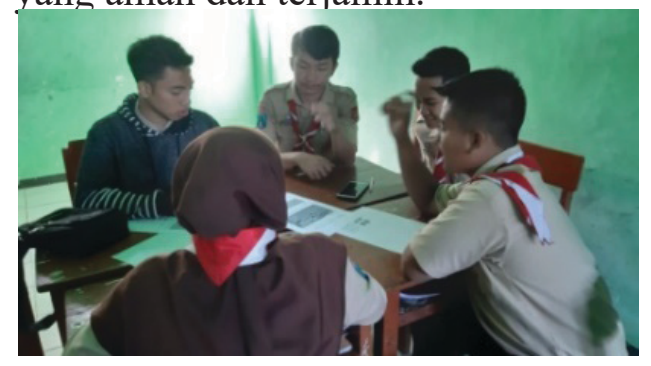

Gambar 2. Pretest awal Literasi

Digital kepada peserta

B. Sesi Kedua "Privasi dan Perlindungan Data Pribadi"

Tujuan diberikan materi ini adalah, peserta bisa mengetahui manfaat berbagi informasi secara online, juga risiko keamanan dan keselamatan berbagi (share) jenis informasi tertentu. Selain itu, peserta bisa memahami jenis informasi apa yang membawa risiko pencurian identitas dan penipuan lainnya, bisa membedakan informasi pribadi yang aman dan tidak aman untuk dibagikan secara online.

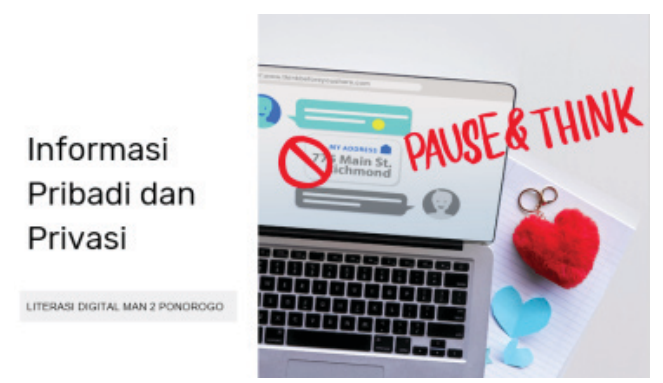

Gambar 3. Materi Informasi Pribadi dan Privasi

Setelah mendapatkan materi, peserta dievaluasi dengan mengisi beberapa pertanyaan yang dibagi menjadi tiga jenis soal yaitu: analisis, multiple choice dan mencocokkan. Isi dari pertanyaan ditampilkan pada gambar 3.

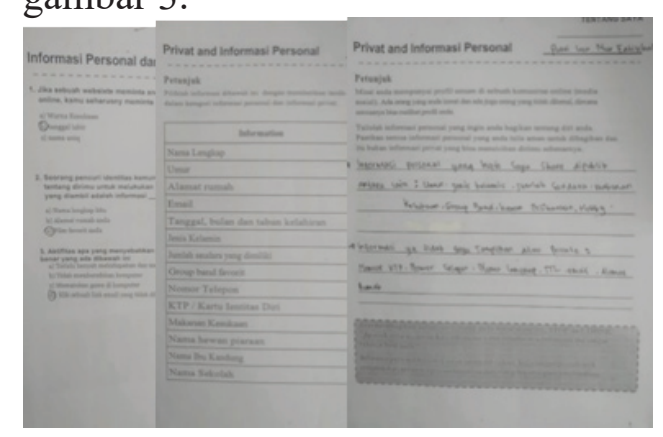

Gambar 4. Soal Evaluasi Informasi Pribadi dan Privasi

Hasil dari evalusai 38 peserta pada sesi informasi personal dan privasi, didapatkan data sebagai berikut:

1. Analisis jawaban Essai. Jawaban dari seluruh peserta bervariasi, karena ada beberapa peserta yang masih menganggap informasi privasi adalah informasi personal yang bisa ditampilkan secara umum seperti di media sosial.

2. Analisis jawaban mencocokkan. Soal mencocokan, merupakan pemantapan dari soal pertama essai tentang informasi personal dan privasi. 
Tabel 1. Analisis jawaban mencocokkan

\begin{tabular}{lcccc}
\hline \multicolumn{1}{c}{ Pertanyaan } & Jawaban & $\begin{array}{c}\text { Benar } \\
\text { (siswa) }\end{array}$ & $\begin{array}{c}\text { Salah } \\
\text { (siswa) }\end{array}$ & \% benar \\
\hline Nama Lengkap & privasi & 28 & 10 & 73,68421 \\
Umur & personal & 32 & 6 & 84,21053 \\
Alamat rumah & privasi & 27 & 11 & 71,05263 \\
Email & privasi & 26 & 12 & 68,42105 \\
Tanggal, bulan dan tahun & privasi & 28 & 10 & 73,68421 \\
kelahiran & & & & \\
Jenis Kelamin & personal & 33 & 5 & 86,84211 \\
Jumlah saudara yang & personal & 34 & 4 & 89,47368 \\
dimiliki & Personal & 36 & 2 & 94,73684 \\
Group band favorit & privasi & 30 & 8 & 78,94737 \\
Nomor Telepon & privasi & 29 & 9 & 76,31579 \\
KTP / Kartu Ientitas Diri & personal & 33 & 5 & 86,84211 \\
Makanan Kesukaan & personal & 34 & 4 & 89,47368 \\
Nama hewan piaraan & privasi & 30 & 8 & 78,94737 \\
Nama Ibu Kandung & privasi & 28 & 10 & 73,68421 \\
Nama Sekolah & 80,45113 & & & \\
\hline rata-rata & & &
\end{tabular}

Berdasarkan tabel 1, lebih dari $80 \%$ peserta bisa membedakan antara kategori privasi dan personal. Namun masih ada beberapa peserta yang masih lemah dalam mengakategorikan informasi privasi.

3. Analisis jawaban soal Multiple

\section{Choice}

dan menjelaskan definisi dari "jejak digital" dan pengaruhnya terhadap privasi online. Kedua, menganalisis bagaimana jejak digital yang ditinggalkan bisa mempengaruhi orang lain dalam menilai seseorang

Tabel 2. Analisis Jawaban Multiple Choice

\begin{tabular}{lcc}
\hline \multicolumn{1}{c}{ Pertanyaan } & Benar & Salah \\
\hline $\begin{array}{l}\text { Jika sebuah websiste meminta anda memberikan........ lewat } \\
\text { online, anda seharusnya meminta pertimbangan orang tua atau }\end{array}$ & $89 \%$ & $11 \%$ \\
guru anda ! & & \\
$\begin{array}{l}\text { Seorang pencuri identitas kemungkinan tidak akan bisa } \\
\text { mengambil informasi tentang dirimu untuk melakukan } \\
\text { aktifitas yang merugikan, apabila informasi yang diambil } \\
\text { adalah informasi ............ }\end{array}$ & $94 \%$ & $6 \%$ \\
$\begin{array}{l}\text { Aktifitas apa yang menyebabkan komputer akan terkena virus, } \\
\text { pilihlah jawaban benar yang ada dibawah ini .... }\end{array}$ & $73 \%$ & $23 \%$ \\
\hline Rata-rata & $\mathbf{8 5 \%}$ & $\mathbf{1 5 \%}$ \\
\hline
\end{tabular}

Dari tabel 2, mayoritas $80 \%$ dari seluruh peserta bisa memberikan jawaban yang benar.

A. Sesi ketiga "Jejak Digital"
Pada sesi ini, peserta diajak
untuk menonton video dan materi
jejak digital. Tujuan dari sesi ketiga
ini, pertama, peserta memahami dalam konteks positif atau negatif dan ketiga bagaimana cara menciptakan jejak digital yang positif dimasa depan dan cara mengontrolnya. Contoh materi bisa dilihat pada gambar 5 . 


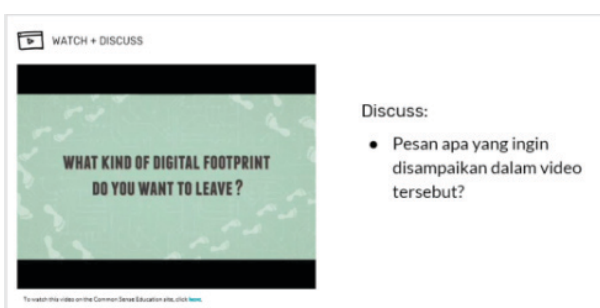

Gambar 5. Contoh materi video jejak digital

Setelah diberi materi, peserta dipisah menjadi beberapa kelompok, satu kelompok terdiri dari delapan anggota (total ada lima kelompok). Tiap kelompok, diberikan tugas untuk mengevaluasi studi kasus tentang dua kandidat yang mendaftar untuk menjadi host sebuah acara tertentu. Evaluasi dinilai berdasarkan informasi tentang curiculum vitae yang sudah diisi oleh calon host. Infromasi lain yang perlu di lihat dengan mencari nama calon host tersebut di Google dan media sosial. Berdasarkan informasi yang didapatkan, tiap kelompok harus bisa memutuskan mana diantara dua calon host tersebut yang layak untuk menjadi host berdasarkan jejak digital yang ditinggalkan oleh kedua calon tersebut, dengan ketentuan penilaian calon host yang terpilih adalah yang bisa bekerja sama dengan team dan bekeria jujur (gambar 6).
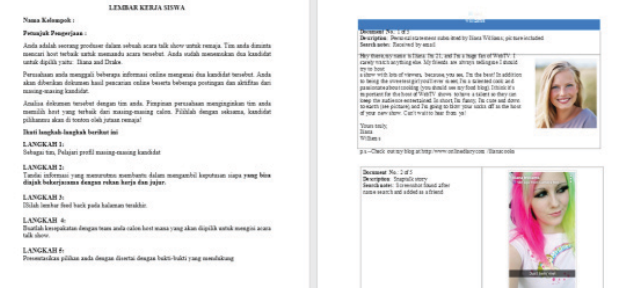

Gambar 6. Contoh studi kasus menganalisis jejak digital

Kelompok yang berhasil menjawab dengan tepat berdasarkan kriteria penilaian bisa bekerja sama dan bekerja jujur, hanya tiga kelompok dari lima kelompok yang ada. Jawaban yang benar untuk kasus ini adalah, dua kandidat host tersebut tidak layak untuk dijadikan host sebuah acara, karena dua-duanya meninggalkan jejak digital yang terkesan negatif meskipun itu hanya sedikit.

Setelah aktivitas berkelompok selesai, dilanjutkan dengan evaluasi secara individu untuk mengetahui pemahaman materi jejak digital oleh seluruh peserta. Evaluasi berupa multiple choice dan essai seperti yang ditunjukkan pada gambar 7 .

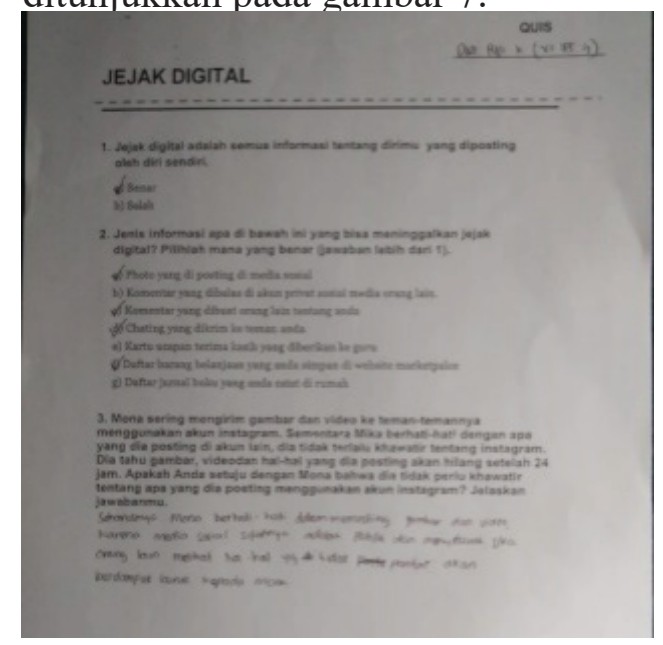

Gambar 7. Salah satu jawaban peserta dari evaluasi jejak digital

Analisis jawaban pertanyaan soal Multiple Choice Jejak Digital terlihat pada tabel 3. 
Tabel 3. Analisis Jawaban Multiple Choice

\begin{tabular}{lcc}
\hline \multicolumn{1}{c}{ Pertanyaan } & Benar & Salah \\
\hline $\begin{array}{l}\text { Jejak digital adalah semua informasi tentang dirimu yang diposting oleh diri } \\
\text { sendiri }\end{array}$ & $78 \%$ & $22 \%$ \\
$\begin{array}{l}\text { Jenis informasi apa di bawah ini yang bisa meninggalkan jejak digital? } \\
\text { Pilihlah mana yang benar }\end{array}$ & $66 \%$ & $35 \%$ \\
$\begin{array}{l}\text { Mona sering mengirim gambar dan video ke teman-temannya menggunakan } \\
\text { akun instagram. Sementara Mika berhati-hati dengan apa yang dia posting } \\
\text { di akun lain, dia tidak terlalu khawatir tentang instagram. Dia tahu gambar, }\end{array}$ & $84 \%$ & $16 \%$ \\
$\begin{array}{l}\text { video dan hal-hal yang dia posting akan hilang setelah 24 jam. Apakah } \\
\text { Anda setuju dengan Mona bahwa dia tidak perlu khawatir tentang apa yang } \\
\text { dia posting menggunakan akun instagram? Jelaskan jawabanmu }\end{array}$ & \\
\hline \multicolumn{1}{c}{ Rata-rata } & $\mathbf{7 6 \%}$ & $\mathbf{2 4 \%}$ \\
\hline
\end{tabular}

Berdasarkan tabel 3, $76 \%$ dari seluruh peserta bisa memberikan jawaban yang benar tentang pemahaman jejak digital.

D. Sesi ke Empat "Keamanan WI FI Publik"

Pada sesi keempat, peserta diberi pelatihan bagaimana menggunakan WI-FI yang aman saat berada di tempat umum. Tujuan dari pelatihan ini: Pertama peserta mempelajari tentang jaringan Wi-Fi publik, manfaat dan risikonya. Kedua, peserta bisa menganalisis Wi-Fi yang tidak aman, memahami untung-rugi dari penggunaan Wi-Fi yang tidak aman. Ketiga, peserta bisa membuat keputusan mengenai saat yang tepat untuk terhubung dan menggunakan Wi-Fi yang tidak aman.

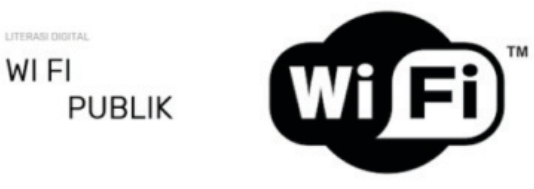

Gambar 8. Materi "Keamanan WI-FI Publik"

Untuk mengetahui kompetensi yang dimiliki oleh peserta tentang pengetahuan mereka dalam penggunaan WI-FI, peserta dipecah menjadi 12 kelompok dengan jumlah anggota 3-4 peserta. Tiap kelompok diberikan soal analisis penggunaan WI-FI beserta resiko kemanan data yang dihadapi seperti yang ada pada gambar 8 .

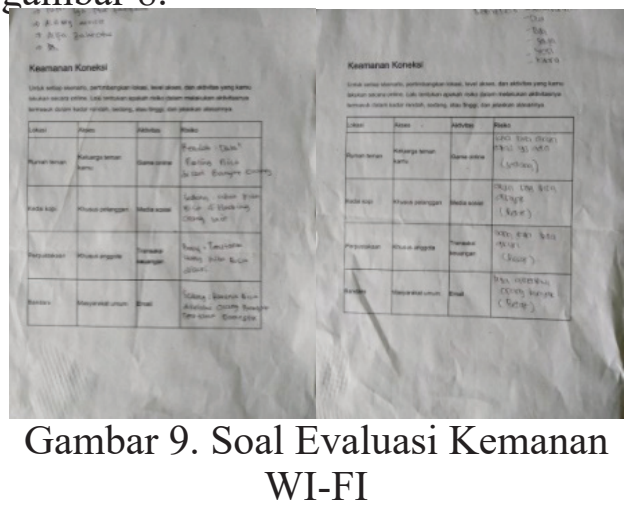

Hasil analisis "Keamanan WIFI Publik", tampak pada tabel 5. Hal ini terkait kompetensi yang dimiliki oleh peserta terhadap penggunaan wi-fi yang aman, mayoritas semua kelompok sudah bisa membedakan aktifitas online yang aman dilakukan saat terhubung dengan wi-fi publik. 
Tabel 5. Hasil Analisis WI-FI publik

\begin{tabular}{lllccc}
\hline \multicolumn{1}{c}{ Lokasi } & \multicolumn{1}{c}{ Akses } & Aktivitas & Resiko & Jawaban Benar & Jawaban Salah \\
\hline Rumah teman & Keluarga teman & Game Online & Rendah & 7 Kelompok & 5 kelompok \\
Kedai Kopi & Khusus pelanggan & Media Sosial & Sedang & 10 Kelompok & 2 kelompok \\
Perpustakan & Khusus anggota & Transaksi Keuangan & Tinggi & 8 Kelompok & 4 kelompok \\
Bandara & Masyarakat umum & Email & Tinggi & 9 kelompok & 3 kelompok \\
\hline
\end{tabular}

E. Sesi kelima Sosialisasi Literasi

Digital Kepada Lingkungan

Sekolah.

Setelah mendapatkan materi dan pelatihan literasi digital, semua peserta bersama instruktur diajak untuk mereview kembali materi yang sudah didapatkan. Hal-hal penting yang apa yang didapatkan dari pelatihan yang bisa kita bagikan kepada warga sekolah, dengan tujuan untuk mengkampanyekan pentingnya literasi digital bagi warga sekolah

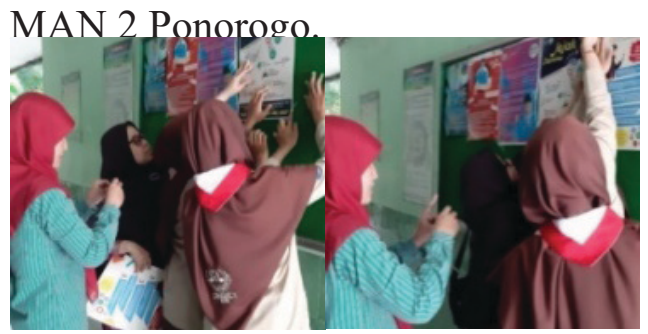

Gambar 8. Sosialisasi Melalui Media Poster

Bentukkampanyeyangdilakukan, adalah dengan menempelkan posterposter di papan pengumuman yang ada di sekolah sehingga semua warga sekolah bisa membaca pesan-pesan literasi digital yang ingin disampaikan. Proses pemasangan poster bisa dilihat pada gambar.

\section{F. Evaluasi Pelaksanaan Kegiatan}

Evaluasi pelaksanaan kegiatan ini menggunakan kuesioner. Hasil evaluasi disajikan dalam bentuk tabel. Target kuesioner, adalah siswa Madrasah Aliyah Negeri II Ponorogo kelas XI 4 sebanyak 40 siswa. Siswa yang mengumpulkan hasil kuesioner sebanyak 38 peserta.

Penghitungan hasil kuesioner menggunakan metode Skala Likert, yang digunakan untuk menghitung persepsi, opini atau pendapat responden. Kuesioner terdiri dari 10 pernyataan. Pertanyaan Evaluasi Pelatihan Penyuluhan Literasi Digital di MAN II Ponorogo, dinyatakan pada tabel 6

Tabel 6. Pertanyaan Evaluasi Pelatihan Startup Digital

\begin{tabular}{|c|c|c|c|c|c|c|}
\hline No & Pernyataan & $\begin{array}{c}\text { Kurang } \\
\text { Sekali }\end{array}$ & Kurang & Cukup & Baik & $\begin{array}{c}\text { Baik } \\
\text { Sekali }\end{array}$ \\
\hline 1 & $\begin{array}{l}\text { Materi literasi digital mudah dipahami dan } \\
\text { dimengerti }\end{array}$ & 0 & 0 & 8 & 9 & 21 \\
\hline 2 & $\begin{array}{l}\text { Materi yang diberikan relevan dengan } \\
\text { objektivitas pelatihan }\end{array}$ & 0 & 0 & 7 & 12 & 19 \\
\hline 3 & Penguasaan materi instruktur pada pelatihan & 0 & 0 & 8 & 10 & 20 \\
\hline 4 & Gaya penyampaian materi instruktur & 0 & 0 & 7 & 10 & 21 \\
\hline 5 & Kejelasan dalam penyampaian oleh instruktur & 0 & 0 & 6 & 12 & 20 \\
\hline 6 & $\begin{array}{l}\text { Kemampuan menjawab pertanyaan oleh } \\
\text { instruktur }\end{array}$ & 0 & 0 & 4 & 9 & 25 \\
\hline 7 & $\begin{array}{l}\text { Tempat pelatihan mendukung kenyamanan } \\
\text { dalam belajar }\end{array}$ & 2 & 4 & 11 & 5 & 16 \\
\hline 8 & Sajian coffe break/snack yang diberikan & 0 & 0 & 4 & 12 & 22 \\
\hline 9 & Sajian makan siang yang diberikan & 0 & 5 & 5 & 8 & 20 \\
\hline \multirow[t]{2}{*}{10} & Kesimpulan umum secara keseluruhan & 0 & 2 & 6 & 9 & 21 \\
\hline & Jumlah & 2 & 11 & 66 & 96 & 205 \\
\hline
\end{tabular}


Berdasarkan interpretasi skor perhitungan, jumlah skala tertinggi untuk item "Baik Sekali" adalah $5 \mathrm{x}$ $380=1900$, sedangkan skala terendah untuk item "Kurang Sekali" adalah 1 x $380=380$. Dengan menggunakan rumus index untuk mengetahui interval (rentang jarak) dan interpretasi persen, kriteria interpretasi skor:

- Angka 0\% - 19,99\% = Kurang Sekali

- Angka 20\% - 39,99\% = Kurang

- Angka 40\% - 59,99\% = Cukup

- Angka 60\% - 79,99\% = Baik

- Angka 80\% - 100\% = Baik Sekali

Berdasarkan Kuesioner Evaluasi Pelatihan Literasi Digital di MAN 2 Ponorogo, didapat hasil dengan jawaban Kurang Sekali sebanyak 2, Kurang 11, Cukup 66, Baik 96 dan Baik Sekali sebanyak 205. Total perhitungan skornya adalah $2+22+198+384+1025=1631$.

Dengan menggunakan Rumus Index $100 \%=$ Total Skor $/$ Y x $100=$ $1631 / 1900 \times 100$, didapat hasilnya sebesar $85 \%$ atau baik sekali. Artinya responden merespon dengan penilaian Sangat Baik dengan adanya pelatihan literasi digital di MAN2 Ponorogo.

\section{SIMPULAN}

Berdasarkan evaluasi workshop literasi digital, peserta merespon dengan baik materi dan evaluasi kompetensi yang diharapkan memenuhi standard oleh semua peserta. Peserta mampu mengikuti dengan baik dan memahami semua materi informasi personal dan privasi, jejak digital dan kemanan WI-FI.

\section{DAFTAR PUSTAKA}

APJII, A. J. P. I. I. (2018). Infografis Penetrasi \& Perilaku Pengguna Internet Indonesia. Teknopreuner, 1(Hasil Survei Penetrasi dan Perilaku Pengguna Internet Indonesia 2017), 1-39.

Aprilia, L. (2014). Pengaruh Internet Terhadap Akhlak Siswa Kelas XI SMA Negeri 1 Jatisrono. http://eprints.ums. ac.id/30832/15/02._NASKAH_ PUBLIKASI.pdf

CNN. (2018). KPAI Sebut Tren Kasus Pornografi dan Cyber Crime Meningkat. 11/11/2018.

Kemenkominfo. (2017). Survey Penggunaan TIK Serta Implikasinya terhadap Aspek Sosial Budaya Masyarakat.

Puspito, D. W. (2015). Implementasi Literasi Digital Dalam Gerakan Literasi Sekolah. Konferensi Bahasa Dan Sastra II International Conference on Language, Literature, and Teaching, 304-399. http:// indonesia.unnes.ac.id/wpcontent/uploads/2017/10/C-DPROSIDING-KBS 2-UNNES2-320-415.pdf

Salainty, F. R., Walandouw, A., \& Rondonuwu, S. (2015). Pengaruh Permainan Internet Terhadap Perilaku Remaja di Kelurahan Karombasan Utara. Acta Diurna, IV(4), 1-12. https://media.neliti.com/ media/publications/92641-IDpengaruh-permainan-internetterhadap-per.pdf

Syaripudin, A., Ahmad, D., \& Widya Ningrum, D. (2017). Kerangka Literasi Digital Indonesia (D. BU (ed.)).

Tim GLN Kemendikbud. (2017). Materi Pendukung Literasi Digital. In L. A. Mayani (Ed.), Kementerian Pendidikan dan Kebudayaan. Kementerian Pendidikan dan Kebudayaan. 
http://gln.kemdikbud. go.id/glnsite/wp-content/ uploads/2017/10/literasiDIGITAL.pdf

Triastuti, E., Prabowo, A. I., \& Napis, H. V. (2017). PETA JALAN PERLINDUNGAN ANAK INDONESIA DI INTERNET.

Urrohman, A. (2018). Pengaruh Penggunaan Internet terhadap Perilaku Siswa dalam Mencari Informasi di SMP N 2 Lohbener. https://doi.org/10.1017/ CBO9781107415324.004 